\title{
Organisatorisk læringskapacitet: Konceptualisering og undersøgelse af et begreb
}

\author{
Af Ulrik Brandi og Jens Breum *)
}

\begin{abstract}
Resumé
Denne artikel har til formål at introducere begrebet 'organisatorisk læringskapacitet', som det kommer til udtryk og konceptualiseres inden for studiet af organisationer og ledelse med særligt henblik på forskningsområdet organisatorisk læring. Artiklen bruger analyseresultater fra en empirisk undersøgelse i danske virksomheder til at skabe viden om og nuancere forskningen og virksomhedernes forståelse af organisatorisk læringskapacitet. Artiklen bidrager på to fronter. For det første præsenterer og udvikler artiklen eksisterende viden om, hvordan begrebet 'organisatorisk læringskapacitet' skal forstås, teoretisk og analytisk. For det andet nuanceres potentialer og begrænsninger i vores viden om begrebet, samt hvordan virksomheder konkret kan arbejde med organisatorisk læringskapacitet i deres ledelsespraksis og organisering af læring i organisationer.
\end{abstract}

\section{Emneord}

Ledelse, læringskapacitet, organisatorisk læring, survey.

*) Til minde om en fantastisk samarbejdspartner, Jens Breum, Videnchef ved Djøfs Kurser og Uddannelser, som gik bort alt for tidligt. Ulrik Brandi er lektor ved Danmarks institut for Pædagogik og Uddannelse, Aarhus Universitet. 


\section{A. Indledning}

\section{Baggrund}

Organisatorisk læring er et velkendt teoretisk felt og empirisk fænomen, som forskningen gennem mere end 50 år har haft et stigende fokus på (Bapuji and Crossan 2004, Argote 2011). Forskningsmæssigt er organisatorisk læring en central del af organisations- og ledelsesstudier og har fra de første videnskabelige arbejder i 1960'erne udviklet et rigt teoriapparat og kvantitative og kvalitative empiriske studier af fænomenet (Brandi and Elkjaer 2014). Parallelt har virksomheder, private såvel som offentlige, længe haft fokus på den strategiske og helt konkret værdimæssige (økonomisk, socialt og miljømæssigt) betydning af at kunne opbygge, arrangere, dele og tilpasse viden, færdigheder og erfaringer, således at de kan fastholde og udvikle deres konkurrencekraft og værdiskabelse (Seo, Putnam, and Bartunek 2004, Easterby-Smith and Lyles 2011).

Det bliver argumenteret af forskere og praktikere, at ustabile og dynamiske sociale, kulturelle, økonomiske og organisatoriske betingelser gør virksomheders muligheder for at lære og tilpasse deres viden, færdigheder og erfaringer afgørende for virksomheders funktionalitet og sammenhæng (Dodgson, Gann, and Phillips 2013, Argote and Miron-Spektor 2011). Noget man inden for det forsknings- og praksisorienterede felter, organisatorisk læring og Den lærende organisation, undersøger gennem begrebet "organisatorisk læringskapacitet". Men hvad karakteriserer i organisations- og ledelsesforskningen - og mere præcist inden for studiet af organisatorisk læring - vores teoretiske viden om læringskapacitet, som overordnet set handler om virksomheders håndtering af videns- og erfaringsprocesser, som de kan udfolde sig i organisationer? $\mathrm{Og} \mathrm{i}$ forlængelse af dette, hvad ved vi mere konkret om den organisatoriske læringskapacitet i en empirisk sammenhæng. Disse to relaterede nysgerrigheder udgør afsættet for denne artikel.

\section{Formål}

Hovedparten af den nyere forskning i organisatorisk læringskapacitet har sat fokus på to forskellige forskningsmæssige tilgange til fænomenet. En tilgang har været at sætte fokus på forholdet mellem organisatorisk læringskapacitet og forskellige typer af output, som fx innovationsformåen og økonomisk eller forretningsperformance. Fx undersøger Alegre og Chiva (2013), hvordan læringskapaciteten påvirker innovationsperformance, og viser at der er en positiv korrelation. I et andet studium inden for denne tilgang viser Hailekiros og Renyong (2016), at den organisatoriske læringskapacitet har direkte positiv effekt på forretningsperformance.

I den anden tilgang er fokus på, hvordan forskellige inputs, fx ledelsestyper eller særlige involverende Human Ressource praksisser, påvirker den organisatoriske læringskapacitet, hvor det måske ikke overraskende viser sig, at transformative, bløde og mere inddragende ledelsesstile har en positiv effekt på læringskapaciteten (Escrig et al., 2016; Xie, 2019). På trods af en markant udvikling af undersøgelser, teorier og redskaber til måling af organisationers læringskapacitet siden 
1990'erne, understreger den nyere forskningen og praksis dog, at vores viden ofte er baseret på single case studier, primært ledelsesudsagn eller case data fra en type branchevirksomhed (Graham and Nafukho 2007, Chiva, Alegre, and Lapiedra 2007).

På baggrund af denne korte oversigt over viden om læringskapacitet, så mener vi, at forskningen og virksomhederne mangler viden og indsigter fra en bredere og mere sammensat virksomhedskontekst end alene at være baseret på ledelsesinterview eller single case studier. Selvom der inden for organisatorisk læring, udvikling og innovation allerede er arbejdet med undersøgelser af relaterede forskningsfelter, som fx innovationskapacitet og læringskultur, så dækker felterne ikke præcist, hvad der menes med organisatorisk læringskapacitet. Relevansen af en introduktion og undersøgelse af begrebet 'organisatorisk læringskapacitet' er yderligere vigtig, da begrebet åbner op for en nødvendig og vigtig "samtale" mellem to tæt relaterede og dog afkoblede forskningsfelter, det klassisk analytiske "organisatorisk læring" greb og den normative og praksisrettede "Den lærende organisation. Hensigten er således ikke kun at bidrage med viden om organisatorisk læringskapacitet, men også et skridt mod at udvikle organisatorisk læringsfeltet yderligere, så det bliver aktuelt og gældende for både den akademiske arena og værdifuldt for virksomhederne.

Forskningsspørgsmålet for denne artikel er i forlængelse af ovenstående: hvad karakteriserer, teoretisk og empirisk, begrebet og foenomenet organisatorisk loeringskapacitet belyst og diskuteret ud fra en undersøgelse af udvalgte dansk virksomheder? Formålet med denne artikel er hermed at analysere og diskutere, hvad der karakteriserer organisationers muligheder for at lære gennem en undersøgelse af begrebet og fænomenet "organisatorisk læringskapacitet". Undersøgelsen og diskussionen har relevans for både forskningen i organisatorisk læring såvel som for praktikere, der arbejder med at skabe forudsætninger for læring i organisationer. Bidraget har således til hensigt at bringe viden og diskussioner fra den forskningsbaserede viden om organisatorisk læringskapacitet inden for organisations- og ledelsesstudier ind i dansk kontekst. Besvarelsen baserer sig på en deskriptiv analyse og undersøgelse af data fra danske organisationer med afsæt i nyeste viden fra forskningsfeltet organisatorisk læring.

\section{Oversigt}

Artiklen er struktureret i fem sektioner. I den første sektion præsenteres den teoretiske baggrund for organisatorisk læring med særlig henblik på at bestemme, hvordan man i teorifeltet forstår begrebet organisatorisk læringskapacitet. I den anden sektion gennemgås den metodiske baggrund for den deskriptive empiriske undersøgelse med fokus på udvikling af survey og dataanalyse. I den tredje sektion præsenterer vi udvalgte resultater fra undersøgelsen, som træder frem som særlige signifikante temaer i data. I den fjerde sektion diskuteres de teoretiske og praktiske implikationer af undersøgelsen. Endelig konkluderer vi på artiklens forskningsspørgsmål i den sidste sektion. 


\section{B. Konceptualisering af organisatorisk læringskapacitet}

Denne artikel undersøger teoretisk og empirisk begrebet 'organisatorisk læringskapacitet', som betegner en organisations kapacitet eller evne til at opbygge, integrere, udvikle, anvende og dele viden og erfaringer dannet i og omkring organisationen. Vi følger hermed DiBella et al. (1996) og Goh og Richards (1997) klassiske bestemmelse, der definerer læringskapacitet ud fra, hvordan særlige organisatoriske karakteristika eller faktorer kommer til udtryk, som understøtter organisatoriske læreprocesser og skaber oplevede muligheder (og umuligheder) for organisationens læring. Ved at undersøge begrebet om organisatorisk læringskapacitet sætter vi hermed fokus på at tydeliggøre den konceptuelle form og indhold formen af en teori og fænomen, som indtager en vigtig plads inden for forskningsområdet organisatorisk læring. Parallelt med den teoretiske og analytiske forskning, som tilbyder forskellige konceptuelle rammer og begreber til at forklare og forstå organisationers læring, har der inden for feltet udviklet sig en tæt koblet tilgang betegnet 'Den lærende organisation' (Easterby-Smith and Lyles 2011, Senge 1990). Denne tilgang er karakteriseret ved mere handlingsrettede og normative modeller for, hvordan man bliver en lærende organisation. Den lærende organisation sætter fokus på de faktorer og betingelser, der understøtter og styrker virksomheders læringssystemer og dermed deres evne til at lære. Organisatorisk læringskapacitet er inden for begge felter et organisatorisk fænomen, som karakteriserer mulighederne for organisationers læreprocesser, hvor organisationen i forhold til dette begreb skal forstås som værende ét læringssystem (Goh 2003, Chiva-Gómez 2004, Chiva 2007, Bontis, Crossan, and Hulland 2002, Marsick and Watkins 2003).

En primær drivkraft bag etableringen og videreudviklingen af teorien bag og redskaber til at operationalisere begrebet er forskerne Chiva og Alegreb (2004, 2007), som understreger, at selvom afsættet for arbejdet med at undersøge og lede organisationers læringskapacitet primært stammer fra den handlingsorienterede del af feltet, så har den empiriske og teoretisk analytiske forskning bidraget med vigtige teoretisk input til vores viden om, hvad der fremmer læring i organisationer. På den måde kan begrebet organisatorisk læringskapacitet ses som et forsøg, som det også nævnes af feltets bidragsydere, der forsøger at bygge bro mellem ideer og analytiske begreber til at forstå mulighederne for organisatorisk læring, og udviklingen af konkrete modeller og normative forslag til, hvordan man understøtter Den lærende organisation. Fokus er således for organisatorisk læringskaapcitet, hvordan gør man et abstrakt analytisk teoretisk felt relevant for organisationer og virksomheder, som til daglig er udfordret med, hvordan man helt konkret arbejder med at skabe læring på et organisatorisk niveau.

Når man skal præsentere de konceptuelle rammer såvel som faktorerne bag organisatorisk læringskapacitet, så sker det inden for feltet ud fra at arbejde med hovedtilgangene fra organisatorisk læring, hvoraf der overordnet er tale om tre (Brandi and Elkjaer 2014, Brandi and Iannone 2017). I en adfærds- og erfaringsorienteret tilgang til organisatorisk læring er fokus på, at 
organisationer lærer, når de over tid reagerer på ydre og indre stimulus og erfaringer ved at udvikle nye rutiner for adfærd. Rutiner rummer elementer som 'skemaer, regler, procedurer, konventioner, strategier og teknologier', som repræsenterer organisationens adfærd, og som det er ledelsens opgave at styre i ønsket retning (Levitt and March 1988). Inden for dette perspektiv vil understøttende faktorer, som danner grundlag for organisationens læringskapacitet, primært være repræsenteret ved særlige organisationsstrukturer, rutiner, incitamenter og ledelsesformer. For eksempel anvender Preskill \& Torres (1999) og Marsick \& Watkins (2003) i deres arbejder om organisatorisk læringskapacitet dimensioner som fx belønning og anerkendelse, strukturer og systemer og tydelig organisering og ledelse af viden og erfaringsprocesser, som faktorer af stor betydning for identificeringen af og det konkrete arbejde med at forstå og styrke organisationers læringskapacitet.

I en anden overordnet tilgang til organisatorisk læring, det handlings- og viden orienterede spor, retter forståelsen af læring sig mod mulighederne for produktiv læring i det eksisterende læringssystem i en pågældende virksomhed (Chiva, Alegre, and Lapiedra 2007). Argyris \& Schön (1996) er vigtige repræsentanter for denne tilgang til organisatorisk læring teoretisk og, i adapteret form, organisatorisk læringskapacitet. Den organisatoriske læring aktualiseres hos de organisatoriske medlemmer, som lærer på vegne af organisationen som enten single eller double loop læring. Den organisatoriske læringskapacitet forstås hos Argyris og Schön konceptuelt som mulighederne for organisatoriske søge og udforskningsprocesser. Disse processer kan være mere eller mindre defensive eller produktive afhængigt af det organisatoriske læringssystems tilstand. Det produktive organisatoriske læringssystem med en høj kapacitet for læring karakteriseres af Argyris \& Schön (ibid.: 120), og i senere udviklinger af fx Lipshitz et al. (2002), ud fra faktorer som tolerance over for risikoer og fejl, være committet til at ville lære og udvikle sig, åben og ærlig feedback og dialog, turde eksperimentere og involvere de organisatoriske medlemmer i beslutningsprocesser. Nævnte faktorer understreges som vigtige af fx Alegre og Chiva (2008), Marsick og Watkins (2003) og Preskill og Torres (1999) i deres forståelse og undersøgelse af organisatorisk læringskapacitet.

Den tredje overordnede teoretiske tilgang, det praksis- og kulturorienterede, understreger betydningen af de sociale interaktioner og kulturelle set-up i organisationen, som tilbyder særlige betingelser for udfoldelsen af lærings- og videnprocesser (Brown and Duguid 2001, Gherardi 2006, Elkjaer 2004). Sociale og kulturelle aspekter som deltagelse, mening, engagement og praksisfællesskaber viser aftegningen af en anden analytisk tilgang til, hvordan vi skal begribe læring. Denne forståelse ser på læring som andet end et overførelsesproblem af tilegnet viden fra en kontekst til en anden, fx fra en virksomhed til en anden virksomhed eller fra uddannelse til praksis (Wenger and Snyder 2000). Udvikling, deling og transformation af viden og kompetencer etableres og skabes gennem deltagelse og situerede handlinger i en given praksis under nogle 
særlige sociale og kulturelle betingelser, som også understreget i teoretiske og empiriske studier inden for denne tilgang (Brandi and Elkjaer, 2019).

Hvor de forrige to tilganges dimensioner er forholdsvis simple at 'oversætte' fra teori og begreb til dimensioner og betingelser for organisatorisk læringskapacitet, er det sværere med praksistilgangen, da den ikke lige så let kan sættes på formel (Chiva-Gómez 2004). Ofte er undersøgelser inden for praksis-tilgangen gennemført som kvalitative case studier, som er primært rettet mod et deskriptivt og analytisk sigte og indeholder kun få handlingsanvisninger, som fx Thompson (2005) viser i sin undersøgelse af ledelsens forsøg på at styre en stor it-virksomheds praksisfællesskaber. I forhold til læringskapaciteten giver praksis-tilgangen dog vigtig viden, som er værd at inddrage både i kortlægningen af læringskapaciteten, men også som baggrund for, hvordan læring er afhængigt af de sociale markører og kulturelle værdier i organisationen.

I denne sektion har vi gennemgået den teoretiske baggrund for identificeringen af organisationers læringskapacitet gennem tre overordnede tilgange med inspiration fra organisatorisk læringsteori og Den lærende organisation, som hver især bidrager med vigtige dimensioner og faktorer for, hvad der betinger en god evne til at integrere, dele, udvikle og anvende ny viden, færdigheder og praksisser. I det følgende metodeafsnit præsenterer vi en survey til undersøgelse af organisatorisk læringskapacitets i danske virksomheder, og karakteristika for de gennemførte virksomheder samt kort beskrivelse af analysestrategien

\section{Metode}

Metoden indeholder en beskrivelse af den organisatoriske læringskapacitetstest, som er blevet skabet fra et samarbejde mellem forskere fra Aarhus Universitet og en Udviklingschef fra Djøf's udviklings- og uddannelsesafdeling og surveyafdeling med henblik på at afdække betingelser og rammer for læring i private og offentlige virksomheder i Danmark.

\section{Sample og databeskrivelse}

Den organisatoriske læringskapacitet i de danske virksomheder er blevet undersøgt ved at udvikle og anvende et spørgeskema baseret på en kombination af to allerede eksisterende spørgerammer (se beskrivelse i næste metodesektion). Spørgeskemaet blev designet og pilottestet fra slutningen af 2014 og udsendt og gensendt til respondenter i juni måned 2015. Survey blev udsendt som en email baseret undersøgelse. Stikprøven for undersøgelsen kommer fra en database opbygget og vedligeholdt af Djøf, som bredt repræsenterer populationen af private og offentlige virksomheder og forskellige branchetyper i Danmark samt stillingsniveauer, hvor dens medlemmer er ansat. Databasen for stikprøven bestod af ca. 5000 medlemmers e-mail adresser i Djøf's databaser og 1653 
respondenter påbegyndte survey og besvarede enkelte dimensioner, mens 1178 afsluttede undersøgelsen med fuldstændige svar.

Taget i betragtning, at dette er en åben udsendt survey til alle i databasen, er det forventeligt, at der er et stort frafald pga. ugyldige e-mail adresser, medlemmer kan være bortrejst eller skiftet job, og at online surveys generelt har en lav svarprocent (Van Mol 2017). I bortfaldsanalysen har vi ikke, udover frafald pga. rækkefølge af spørgsmål i survey, observeret systematiske bortfald.

En fejlkilde ved at bruge en database oprettet i en fagforening er, at respondenterne tilhører specifikke fagprofessioner. I dette tilfælde respondenter med enten primær økonomisk eller juridisk uddannelsesbaggrund, som repræsenterer specifikke jobtyper og fagligheder i de organisationer, de tilhører. Dette forhold er en klar begrænsning af fortolkningsbredden og dybden i forhold til præsentationen af resultater fra vores deskriptive analyse. I tabel 1 præsenteres nogle udvalgte karakteristika for stikprøven, hvad angår forskellige baggrundsvariabler.

\begin{tabular}{|l|lll|}
\hline Kategori & & Antal & Pct. \\
\hline Stillingsniveau & Ikke-leder & 980 & $83 \%$ \\
& Leder & 197 & $17 \%$ \\
\hline Køn & Kvinde & 1009 & $61 \%$ \\
& Mand & 640 & $39 \%$ \\
\hline Hvilken sektor & & & \\
arbejder du i? & Den offentlige sektor & 770 & $65 \%$ \\
& Den private sektor & 408 & $35 \%$ \\
\hline Alder & Gennemsnit & 42 år & \\
& 25\% percentil & 34 år & \\
& $75 \%$ percentil & 50 år & \\
\hline Virksomhedsstørrelse & $0-50$ ansatte & 226 & \\
& $51-250$ ansatte & 266 & \\
& $251+$ ansatte & 679 & \\
\hline
\end{tabular}

Tabel 1: Beskrivelse af data.

Baggrundvariablen 'leder' indeholdt to informanter fra to forskellige ledelseslag i virksomhederne, som var topledelse/direktion og chef/leder med personaleansvar. Resten af informanterne blev bestemt til at være ikke-leder. I forhold til typer af virksomheder fulgte vi de nationalt og internationalt gældende branchekoder. Da informanter kommer fra en medlemsgenereret database har hovedparten i vores sample en samfundsvidenskabelig uddannelsesbaggrund som cand. jur., cand. merc. og cand. scient. pol., som også er en vigtig fejlkilde, de skal medtænkes i de analytiske betragtninger og resultater. 
I forhold til virksomhedsstørrelse har vi fulgt EU's klassifikation i små- og mellemstore virksomheder (0-250 ansatte) og store virksomheder (+251 ansatte), hvor survey har en repræsentativ sample i forhold til populationen generelt. Vi ser i øvrigt en repræsentativ fordeling på de andre baggrundsvariable set i forhold til den meget åbne indsamlingsmetode og den samlede population bortset fra fordeling af køn, hvor der en overvægt af kvinder.

\section{Spørgeramme og dataanalyse}

Vores anvendte spørgeramme er opbygget på baggrund af koncepter fra litteraturen om Den lærende organisation repræsenteret ved e.g. Peter Senge (1990) og Pedler \& Burgyone (1989) i kombination med indsigter fra et mere kognitivt inspireret læringsteoretisk grundlag fra Argyris \& Schöns teoretiske arbejder. Her forstås organisationen som værende ét læringssystem, der kan være karakteriseret ved at være enten produktivt eller defensivt. Hermed udgår spørgerammerne fra det forhold, at udgangspunktet for at have en tilfredsstillende læringskapacitet er, at der er plads til at afprøve nye ideer, dvs. arbejde på en eksperimenterende måde, man tør tage risikoer, inddrager medarbejdere, kommunikation er åben og ærlig, for blot at nævne nogle af de overlappende dimensioner.

Inden for forskningen er der, som også beskrevet i det teoretiske kapitel, udviklet flere instrumenter, der har til formål at måle organisationers læringskapacitet. Nogle af de mest anvendte og validerede er Readiness for Organizational Learning and Evaluation (ROLE) (Preskill and Torres 1999), Organizational Learning Capacity (OLC) (Alegre and Chiva 2008), Dimensions of the Learning Organization Questionnaire (DLOQ)(Marsick and Watkins 2003) og Organizational Learning Survey $(O L S)$ (Goh, Cousins, and Elliott 2006). De forskellige spørgerammers dimensioner og items er konstrueret på baggrund af review af den eksisterende forskning på området, som også tilfældet er for den udviklede og anvendte survey i denne undersøgelse. Selvom de lokaliserede spørgerammer til at undersøge organisationers læringskapacitet umiddelbart fremstår med forskellig struktur og niveauer, så er de ved konceptuel indholdsanalyse sammenlignelige, idet der er tydelige teoretiske overlap og fælles fundament, når man ser på konceptuel baggrund og dermed også dimensioner og spørgsmål.

På baggrund af en nærmere undersøgelse af spørgerammerne til måling af organisationers læringskapacitet blev det besluttet, at et instrument i sig selv ikke var dækkende for, hvad vi gerne ville undersøge. Beskrivelsen af den organisatoriske læringskapacitet er således ikke direkte anvendelse af en eksisterende spørgeramme, men er udviklet ud fra en kombination af dimensioner og items fra to allerede afprøvede og validerede organisatorisk læringskapacitetstest (Preskill and Torres 1999; Yang, Watkins, and Marsick 2004). Den ene er ROLE (Preskill and Torres 1999), som vi anvendte som det primære instrument med inddragelse af fire dimensioner læringskultur/miljø, ledelse, organisation (i ROLE betegnes dette "system og struktur") og kommunikation. Vi vurderede, 
at evaluerings- og teamsdimensionen ikke passede til vores undersøgelse, og der manglede spørgsmål om oplevede læringsmuligheder, hvorfor vi supplerede med spørgsmål fra DLOQ. Den anden spørgeramme er således DLOQ (Marsick and Watkins 2003), som har betydningsmæssigt overlap med ROLE, hvorfra vi inddrog spørgsmål og læring og organisation (Yang, Watkins, and Marsick 2004).

Målet har været at udvikle en simpel test, der kan besvares på under 15 minutter, der på samme tid tillod tilstrækkelig dybde i forhold til analyse af resultaterne og efterfølgende diskussion af teoretiske og praktiske implikationer på virksomhedsniveau om læringskapaciteten i de undersøgte organisationer. Vi har analyseret og sammenlignet de udvalgte items fra ROLE med items fra andre spørgerammer for at sikre os sammenhæng mellem udvalgte dimensioner og items. Formålet her har haft fokus på at skabe sammenhæng mellem ROLE items og de items fra DLOQ, der vil kunne bidrage til at konstruere en kortere version til måling af den organisatoriske læringskapacitet. Vi har derfor udvalgt spørgsmål - og ikke medtaget alle 78 spørgsmål fra ROLE og 49 spørgsmål fra DLOQ - ud fra et mål om at udvikle en præcis, dækkende og brancherelevant survey, der giver organisationer og forskningen viden om organisatorisk læringskapacitet.

Den endelige læringskapacitetstest består af 4 dimensioner med i alt 21 udvalgte spørgsmål (items) foruden udvalgte baggrundsvariabler. I tabel 2 giver vi et overblik over dimensionerne og variabler i redskabet. 


\begin{tabular}{|c|c|c|}
\hline Dimension & Underdimension & Items \\
\hline \multirow[t]{2}{*}{$\begin{array}{l}\text { Læringsmiljø } \\
\text { (8) }\end{array}$} & $\begin{array}{l}\text { Muligheder for } \\
\text { læring (4) }\end{array}$ & $\begin{array}{l}1 \text { Inddrage medarbejdere i beslutninger } \\
2 \text { Der gives tid til refleksion } \\
3 \text { Medarbejdere evne til at lære prioriteres } \\
4 \text { Åbne for forandring }\end{array}$ \\
\hline & $\begin{array}{l}\text { Medvirken } \\
\text { læring (4) }\end{array}$ & $\begin{array}{l}1 \text { Tør tage risiko og fejl er } \\
\text { læringsmuligheder } \\
2 \text { Fokus på at turde eksperimentere } \\
3 \text { Åben og ærlig feedback } \\
4 \text { Fortløbende fokus på forbedring og } \\
\text { læring }\end{array}$ \\
\hline \multicolumn{2}{|l|}{ Ledelse (5) } & $\begin{array}{l}\text { Forskellige læringsbehov } \\
2 \text { Støtte deling af viden blandt } \\
\text { medarbejdere } \\
3 \text { Der gives tilstrækkelig tid og støtte til } \\
\text { forankring } \\
4 \text { Ledere kommunikerer i forbindelse med } \\
\text { læringsinitiativer } \\
5 \text { Ledere støtte videndeling og læring efter } \\
\text { kursus og udviklingstiltag }\end{array}$ \\
\hline \multicolumn{2}{|c|}{ Organisation (4) } & $\begin{array}{l}1 \text { Medarbejderes læring anerkendes } \\
2 \text { Medarbejdere anerkendes for at støtte } \\
\text { andres læring } \\
3 \text { Forstår organisationens mål } \\
4 \text { Læringsaktiviteter måles og evalueres } \\
5 \text { Medarbejdere møder kun lidt } \\
\text { bureaukrati }\end{array}$ \\
\hline \multicolumn{2}{|c|}{ Kommunikation (3) } & $\begin{array}{l}1 \text { Adgang til nødvendig viden } \\
2 \text { Adgang til ressourcer nødvendige for at } \\
\text { tage beslutninger } \\
3 \text { Der er it-systemer til at opbevare og dele } \\
\text { viden }\end{array}$ \\
\hline
\end{tabular}

Tabel 2: Spørgerammestruktur med 4 dimensioner og 2 underdimensioner.

De fire dimensioner er: 1. Læringsmiljø (8 spørgsmål), 2. Ledelse (5 spørgsmål), 3. Organisation (4 spørgsmål) og 4. Kommunikation og videndeling (3 spørgsmål). Alle dimensionsspørgsmål anvendte en Likert respons skala fra 0-7, hvor 0 var 'helt uenig' og 7 var 'helt enig'. Ifølge forskningslitteraturen bag målinger af organisatorisk læringskapacitet er en tilfredsstillende 
læringskapacitet lig med et gennemsnit for spørgsmål og dimension over 5,0 værdien (Preskill and Torres 1999).

Data blev først analyseret gennem en principal komponent analyse (PCA) for at teste, hvor meget de forskellige dimensioner og spørgsmål kunne forklare af variationen i forhold til måling af virksomhedernes læringskapacitet. PCA testen viste, at der var en skala i hver dimension, som korrelerede med de teoretisk fremstillede dimensioner, men at 'Læringskultur' dimensionen bestod af to forskellige underdimensioner set i forhold til, hvor meget spørgsmålene kunne forklare af virksomhedernes læringskapacitet. Foruden sammenligning af gennemsnit foretog vi signifikansanalyser og Pearson korrelations analyse til at bestemme sammenhænge - ikke kausale af relationen mellem udvalgte variabler. I præsentation af resultater har vi testet for og viser ikke data, som er karakteriseret ved 'violation' af normalitet, ekstremer eller 'outliers'. I den følgende sektion præsenterer vi resultater, hvor vi observerede en stærk korrelation mellem variabler, som var statistisk signifikante.

\section{Resultater}

Dataanalysen fulgte flere skridt. Første skridt var at beskrive gennemsnit for de målte dimensioner. I Tabel 3 præsenterer vi gennemsnit inden for dimensionerne. På baggrund af resultater fra vores PCA test delte vi læringskulturdimensionen op i to underdimensioner. En underdimension med fokus på oplevelsen af medarbejdernes muligheder for læring og en anden underdimension, som målte på oplevelsen af medvirken til læring. Analysen viser derfor gennemsnit på 6 dimensioner.

\begin{tabular}{|l|c|c|c|}
\hline Dimensioner & $\mathbf{N}$ & Gnms & SD \\
\hline 1. Læring & 1296 & 4,6 & 1,3 \\
\hline Sub_laring_medvirken & 1296 & 4,6 & 1,2 \\
\hline Sub_laring_mulig & 1293 & 4,5 & 1,5 \\
\hline 2. Ledelse & 1232 & 3,9 & 1,4 \\
\hline 3. Organisation & 1181 & 3,7 & 1,3 \\
\hline 4. Videndeling & 1183 & 4,4 & 1,3 \\
\hline
\end{tabular}

Tabel 3: Gennemsnit (Gnms) på dimensioner med standardafvigelse (SD).

I forhold til at have et mål om at have en læringskapacitet over værdien 5.0 er de danske virksomheder generelt set i gennemsnit placeret under dette niveau på alle dimensioner. Især på ledelse og organisationsdimensionerne viser beskrivelsen af data et lavt gennemsnit under 4,0. På 
ledelsesdimensionen viser dataanalysen lave gennemsnit på de variabler, som handler om ledelsen - eller anden ansvarlig person for læring og udvikling i organisationen - giver tilstrækkelig tid til at forankre forandringer $(3,7)$, at tale med medarbejdere før, under og efter en uddannelses- og udviklingsaktivitet $(3,8)$, og endelig om ledelsen tager initiativ til deling af viden med kollegaer efter endt uddannelse og udviklingsaktivitet $(3,7)$.

Organisationsdimensionen, som handler om strukturer og systemer, viser at to variabler scorer lave gennemsnitlige værdier. For det første er det oplevelsen af, om virksomheden måler på resultatet af læringsaktiviteter $(3,0)$, som inkluderer både interne og eksterne formelle og informelle læringsaktiviteter. For det andet, at informanten oplever at møde kun lidt bureaukrati, når man forsøger at gøre noget på en ny måde, fx arbejdsproces eller serviceydelse, i virksomheden $(3,9)$. I forhold til den meget lave værdi på, om virksomheden måler på læringsaktiviteters resultater, er det interessant, at informanterne oplever, at virksomheden har systemer, som kan opbevare viden fra deltagelse i både formelle og informelle læringsaktiviteter $(4,4)$. Omvendt bliver disse systemer ikke brugt til at afdække resultatet og virkningen af de gennemførte læringsindsatser i virksomheden. Man ser således på tværs af data en forholdsvis lav score på alle dimensioner og faktorer i forhold til beskrivelsen af de danske virksomheders læringskapacitet, men specielt finder vi værdier i faktorer i ledelses- og organisationsdimensionerne som værende meget lave.

Det andet skridt i analysen bestod i at afdække og beskrive signifikante forskelle i datamaterialet. Vi observerede i analysen flere signifikante forskelle, hvor specielt forskellen mellem leder og ikkeleder samt offentlig og privat virksomhed viste en stærk signifikante forskel på hovedparten af faktorer under de 6 dimensioner.

\begin{tabular}{|c|c|c|c|c|c|c|c|}
\hline \multicolumn{2}{|c|}{$\begin{array}{l}\text { Hvilken sektor } \\
\text { arbejder du i? * }\end{array}$} & \multirow{2}{*}{$\begin{array}{c}\text { Læring } \\
4,5\end{array}$} & \multirow{2}{*}{$\begin{array}{c}\text { Sub_læring_ } \\
\text { medvirken } \\
4,5\end{array}$} & \multirow{2}{*}{\begin{tabular}{|c|}
$\begin{array}{c}\text { Sub_læring } \\
\text { mulig }\end{array}$ \\
4,4
\end{tabular}} & \multirow{2}{*}{$\begin{array}{c}\text { Ledelse } \\
3,9\end{array}$} & \multirow{2}{*}{$\begin{array}{c}\text { Organisation } \\
3,6\end{array}$} & \multirow{2}{*}{$\begin{array}{c}\text { Videndeling } \\
4,3\end{array}$} \\
\hline Den & Gnms & & & & & & \\
\hline offentlige & $\mathrm{N}$ & 769 & 769 & 769 & 767 & 759 & 766 \\
\hline sektor & SD & 1,3 & 1,2 & 1,5 & 1,5 & 1,3 & 1,3 \\
\hline Den & Gnms & 4,7 & 4,8 & 4,7 & 4,1 & 4,0 & 4,6 \\
\hline private & $\mathrm{N}$ & 407 & 407 & 405 & 407 & 402 & 407 \\
\hline sektor & SD & 1,3 & 1,3 & 1,5 & 1,5 & 1,3 & 1,3 \\
\hline
\end{tabular}

Tabel 4. Gennemsnit (Gnms) på baggrundsvariablerne 'privat og offentlig' organisation: *Signifikansniveau <.01 på alle dimensioner. 
I tabel 4 præsenterer vi resultaterne for forskellen mellem læringskapaciteten i offentlige og private organisationstyper. På gennemsnit for alle dimensioner og sub-dimensioner ser vi den samme tendens, nemlig at svarene fra private organisationer viser en højere signifikant gennemsnitlig score end offentlige organisationer. Når man ser mere specifikt i resultaterne på de forskellige items, observeres den samme signifikante forskel. Der er dog et par items, hvor der ikke er forskel på oplevelsen af læringskapaciteten mellem svar fra offentlige og private respondenter, hvilket er i forhold til: 1. om medarbejdere gives tid til refleksion over deres arbejde; 2 . at medarbejdere ser fejl som læringsmuligheder; 3. at ledere og chefer er opmærksomme på, at de ansatte har forskellige læringsbehov og betingelser for læring; 4. at læringsindsatser måles og dokumenteres.

En af de mest markante forskelle i oplevelsen af læringskapaciteten i de adspurgtes organisationer ses i forhold til, om man er 'leder' eller 'ikke-leder'. I tabel 5 viser dataanalysen, at ledere generelt på tværs af alle dimensioner - oplevede læringskapaciteten i deres organisation som højere end ikke-leder variablen.

\begin{tabular}{|c|c|c|c|c|c|c|c|}
\hline \multicolumn{2}{|c|}{$\begin{array}{l}\text { Er du leder eller } \\
\text { ikke-leder? * }\end{array}$} & \multirow{2}{*}{$\begin{array}{c}\text { Laring } \\
5,1\end{array}$} & \multirow{2}{*}{$\begin{array}{c}\text { Sub_læring_ } \\
\text { medvirken } \\
5,0\end{array}$} & \multirow{2}{*}{$\begin{array}{c}\begin{array}{c}\text { Sub_læring } \\
\text { mulig }\end{array} \\
5,2\end{array}$} & \multirow{2}{*}{$\begin{array}{c}\text { Ledelse } \\
4,7\end{array}$} & \multirow{2}{*}{\begin{tabular}{|c|} 
Organisation \\
4,3
\end{tabular}} & \multirow{2}{*}{$\begin{array}{c}\text { Videndeling } \\
4,9\end{array}$} \\
\hline Leder & Gnms & & & & & & \\
\hline & $\mathrm{N}$ & 196 & 196 & 195 & 195 & 192 & 195 \\
\hline & SD & 1,3 & 1,2 & 1,5 & 1,4 & 1,2 & 1,3 \\
\hline \multirow[t]{3}{*}{ Ikke-leder } & Gnms & 4,4 & 4,6 & 4,3 & 3,8 & 3,6 & 4,4 \\
\hline & $\mathrm{N}$ & 980 & 980 & 979 & 979 & 969 & 978 \\
\hline & SD & 1,3 & 1,3 & 1,5 & 1,4 & 1,3 & 1,3 \\
\hline
\end{tabular}

Tabel 5: Gennemsnit (Gnms) på baggrundsvariablerne 'leder og ikke-leder': *Signifikansniveau < .01 på alle dimensioner.

Dataanalysen viser mere specifikt en svag positiv korrelation i forhold til dimensionerne 'oplevelsen af mulighederne for læring' ( $r=.226)$ og 'ledelse' $(r=.218)$, hvor afstanden i vurderingen af læringskapaciteten mellem leder og ikke-leder er mest markant. Man kan konstatere - selvom korrelationen kun er svagt positiv - at der synes at være en forskel i oplevelsen af læringskapacitet mellem de to overordnede niveauer i en virksomhed, ledelse og medarbejdere, som både har vigtige forskningsmæssige såvel som praktiske implikationer. Fx er teorier og empiriske resultater omkring organisationers læringskapacitet domineret af analyser af data baseret på svar fra ledelsen. På baggrund af ovenstående resultater kan denne form for data skævvride "billedet" af en organisations læringskapacitet samt indikere, at oplevelsen af læringskapaciteten afspejler lokale forhold og oplevelser afhængigt af, hvor man befinder sig i organisationen. 
Et sidste fremtrædende resultat fra dataanalysen er identificeringen af en stærk korrelation mellem en organisations læringskapacitet - inden for alle dimensionerne - og jobtilfredshed, hvilket indikerer sammenhæng mellem læringssystemet og arbejdssystemet i en organisation. I den samlede model (se tabel 6) for korrelationen mellem læringskapacitet målt på alle dimensioner og jobtilfredshed kan man forklare $46 \%$ af jobtilfredsheden ud fra læringskapaciteten og baggrundsvariable samlet.

\begin{tabular}{|c|c|c|c|c|}
\hline Model & $\mathbf{R}$ & R Square & Square & estimatet \\
\hline 1 &, $673^{\mathrm{a}}$ &, 453 &, 451 & 1,572 \\
\hline
\end{tabular}

Tabel 6: Model opsummering ${ }^{b}$

1) Predictors: (konstant), gnms_videndeling gmns_læring, gnms_ledelse.

2) Afhængig variabel: Hvor tilfreds er du alt i alt med dit arbejdsliv?

Når man analyserer på de enkelte dimensioner i den organisatoriske læringskapacitetstest måler vi den samme stærke korrelation mellem oplevelsen af muligheder for læring, i organisationen, og hvor tilfreds man er med sit arbejdsliv. Det er i forbindelse med den stærke sammenhæng mellem en organisations læringskapacitet og jobtilfredshed vigtigt at understrege, at læringskapaciteten og jobtilfredsheden er forholdsvis upåvirket af, om organisationer tilbyder megen eller lidt formel læring målt ved antallet af årlige kursusdage. Læringskapaciteten forholder sig primært til de organisatoriske aspekter af dit arbejdsliv, dvs. opfattelsen af læringsmuligheder i praksis, organisering af videndeling og generelle ledelsesmæssige og organisatoriske aspekter, som undersøgelsen har vist læring er betinget af.

Oplevelsen af at kunne udvikle sig og lære på en arbejdsplads er således en stærkt medvirkende variabel i forhold til at skabe jobtilfredshed. Måske ikke det intuitivt mest overraskende fund, men alligevel et resultat, der maner til eftertanke, når organisationer sætter fokus på læring. At arbejde med og lede læring i organisationen er således ikke alene et bidrag til udvikling af nødvendige nye praksisser, rutiner og kompetencer for at holde trit med udviklingen, men er også en aktivitet, som har en indflydelse på motivation og jobtilfredshed på arbejdspladsen helt generelt. 


\section{E. Diskussion}

Denne artikel har haft fokus på at uddybe vores viden om begrebet 'læringskapacitet', som det kommer til udtryk og konceptualiseres inden for studiet af organisationer og ledelse med særligt henblik på forskningsområdet organisatorisk læring. Den teoretiske viden er undersøgt ved gennemførslen af et empirisk studium af den organisatoriske læringskapacitet i danske virksomheder. I diskussionen vil fokus være på både de teoretiske og praktiske implikationer af de teoretiske indsigter og empiriske resultater. Det skal indledningsvist understreges, at et vigtigt forbehold for diskussionen er, at den tager afsæt i viden hentet fra en særlig gruppe medarbejdere og ledere inden for specifikke brancher og uddannelsesbaggrund. Temaerne er dermed mere diskussioner af interessante vinkler og tendenser end generalisering til andre typer af medarbejdere. Det første teoretiske diskussionstema har fokus på, hvad det er for et fænomen man måler og afdækker, når man anvender den udviklede og anvendte spørgeramme (som også dækker de andre spørgerammer på området), som en repræsentation af fænomenet "læringskapacitet" i en organisation. Giver det overhovedet mening at måle på et fænomen, som man antager entydigt korresponderer med noget, der betegnes for en 'læringskapacitet' i en organisation?

En årsag til denne diskussion finder sin relevans i en af undersøgelsens resultater, hvor vi observerede en signifikant forskel på oplevelsen af læringskapacitet mellem leder og medarbejder. De adspurgte ledere konstruerede generelt set et billede af læringskapacitetens tilstand, som markant bedre end medarbejderne. Ofte anvender forskere inden for dette felt primært ledere/mellemledere eller alene medarbejderniveauet som datagrundlag for deres analyser, som det fx ses i klassiske studier af Bontis, Crossan, og Hulland (2002) og Alegre og Chiva (2008), men også i nyere bidrag inden for feltet af fx Mallén et al. (2015) og Jerez-Gómez et al. (2017). Manglen på inddragelse af flere medarbejderniveauer i undersøgelsen af organisationens læringskapacitet åbner op for skævvridninger og ensidige forståelser af fænomenet.

Disse forhold er efter al sandsynlighed med til at påvirke de forskellige medarbejdergruppers praksis og handlinger i arbejdet med læring i organisationen, såvel som det påvirker teoriudvikling inden for et forskningsområde med fokus på læringssystemets kvalitet og sammenhæng. En leder/ledergruppe, som oplever en høj læringskapacitet, vil være tilbøjelig til ikke at arbejde med læring og udvikling, som prioriterede aktiviteter i organisationen, hvis det ikke anset for at være et konkret problem. Endvidere er der en fare for, at man som forsker, ikke har øjne for de dybere analytiske lag i begrebet 'læringskapacitet', hvis man ensidigt kun undersøger et niveau i organisationen.

Læringskapaciteten qua ovenstående teoretiske og analytiske indsigter udtrykker ikke en endelig repræsentation af fænomenet, men er betinget af de forståelser og meninger, de forskellige typer af virksomhedsansatte tilskriver fænomenet. Meninger og forståelser, der således konstrueres 
forskelligt alt efter position, sted og funktion i den pågældende organisation, bør indtænkes i undersøgelser og tiltag i forhold til organisatorisk læring og udvikling. Coopey og Burgoyne (2000) og Ferdinand (2004) har siden starten af 2000 sat fokus på dette tema forstået som betydningen af magt og politik i forhold til organisatorisk læring og Den lærende organisation, og åbnet op for vigtig kritisk analytisk tilgang.

I denne sammenhæng skal man således være forsigtig med for ensidige slutninger omkring vores teoretiske forståelse af læringskapacitet og dermed læringssystemets tilstand og udviklingsmuligheder i organisationer. Indholdet for en sådan ensidig slutning består ved, at man i forskningen inden for organisatorisk læring primært forstår og udvikler på læringskapacitetsbegrebet, som om det alene er et funktionalistisk fænomen, som vi ser i fx Argyris \& Schön's (1996) og senere Alegre \& Chiva's (2008) bidrag. En forståelse af fænomenet, der ikke tager hensyn til markante teoretiske udviklinger inden for feltet gennem den praksis-teoretiske tilgang inden for organisations- og ledelsesstudier siden begyndelsen af 1990'erne, misser vigtige teoretiske og analytiske pointer (Corradi, Gherardi, and Verzelloni 2010, Feldman and Orlikowski 2011, Cetina, Schatzki, and Von Savigny 2005). Pointer, som kan bidrage til at udfordre og udvikle læringskapacitetsbegrebet i nye retninger.

En praksis-teoretisk tilgang understreger vigtigheden af at inddrage aspekter som organisering af arbejdet, hverdagslivets læringsmuligheder, arbejdets art, materialitet, positioner og meningsskabelse og forståelser af læring gennem kollektiver og praksisfællesskaber (Brown and Duguid, 1991; Yanow, 2004; Orlikowski, 2007; Nicolini, 2011). Læring og læringskapacitet bliver således forstået som et socialt og kulturelt betinget fænomen, hvilket også understreger vigtigheden af at supplere kvantitative beskrivelser med dybtgående kvalitative casestudier for at få nuancer og dybde i den teoretiske forståelse af organisationers læringskapacitet (Gherardi, 2000; Elkjaer 2004, Yanow 2004).

En anden teoretisk tematik har fokus på, hvordan læringskapacitet i organisationer forholder sig til udviklinger af andre typer af målinger og begrebsliggørelser af støtte og muligheder for læring og udvikling i organisationer. Inden for human ressource management taler man om high performance work systems (Camps and Luna-Arocas 2012; Jerez-Gómez et al., 2017), mens man inden for arbejdspladslæringsforskningen i de sidste par år har sat fokus på muligheder for ekspansiv læring (Fuller and Unwin, 2004; Felstead et al. 2009). Både den teoretiske forståelse og selve måleredskabet i high performance practices i organisationer såvel som ekspansive læringsmiljøer overlapper med begrebet om organisatorisk læringskapacitet. Inspirationen fra Argyris \& Schön's $(1978,1996)$ teori om produktiv og defensive læringssystemer og litteraturen fra den mere normative del af feltet, fx Den lærende organisation (Senge, 1990) skaber en normativ forståelse om, at idealet for produktive 
læringssystemer er den overskridende og udforskende læring. Argyris \& Schön (1996) betegner denne læringstype for double loop læring.

En kritik af denne forståelse af idealet for læringssystemet finder man helt tilbage i den adfærdsorienterede forståelse af organisatorisk læring hos Simon (1991) og March (1991), som i forhold til teoriudviklingen af organisatorisk læring taler om en balance mellem både den udforskende og udnyttende læringsform i organisationer. En teori, som efterfølgende er blevet undersøgt og empirisk testet af forskere inden for organisations- og ledelsesfeltet (He and Wong 2004, Chen et al. 2016). Pointen er, at organisationer ikke alene skal have fokus på det ekspansive og konstant udviklende, men også skal indeholde en kapacitet for at udnytte eksisterende viden og erfaringer for at kunne fungerer optimalt. Implikationerne fra en sådan kritik for denne artikels undersøgelse er, at den udnyttende del mangler i rammerne til at forstå og måle organisatorisk læringskapacitet. Spørgeskemaet og den bagvedliggende teoretiske ramme mangler simpelthen øje for, at den organisatoriske læringskapacitet også handler om fastholdelse og udnyttelse af ny viden og rutiner fra deltagelse i diverse læringsaktiviteter og ledelsestiltag.

Et tredje tema fra analysen er forholdet mellem læringskapacitet og jobtilfredshed, som kort blev præsenteret og diskuteret i resultatsektionen. Kun få studier har undersøgt dette forhold. Eksempelvis har Chiva \& Alegre (2009) empirisk undersøgt relationen mellem organisatorisk læringskapacitet og jobtilfredshed. Deres resultat viser, som også indeværende deskriptive analytiske resultater, at der helt generelt synes at være en positiv korrelation mellem organisatorisk læringskapacitet og jobtilfredshed. Det bliver dog understreget, at der mangler yderligere viden i form af empiriske studier, der udfører mere dybtgående undersøgelser af forholdet, såvel som det relation til organisatorisk performance. Man kunne i denne forbindelse tænkes at styrke og udvikle viden om organisationers læringskapacitet ved at koble direkte til eksisterende virksomhedsdata, som fx arbejdspladsmiljøvurderinger og jobtilfredshedsundersøgelser.

Litteraturen om organisatorisk læringskapacitet understreger, at der ikke er enighed omkring, hvordan ledere kan understøtte og styrke virksomhedens læringspotentialer. Denne artikel har udviklet og anvender fire dimensioner, som ledere og læringsansvarlige bør tage i betragtning for at styrke læringskapaciteten, og dermed arbejde aktivt med at understøtte organisationens læring og udvikling. I forhold til de praktiske implikationer er der et potentiale for ledere $\mathrm{i}$ at anvende målingstesten, som et redskab der på overordnet vis kan skitsere læringsbetingelserne i organisationen såvel som fungere som et dialogredskab til, hvordan man arbejder med læring og udvikling i sin organisation. Redskabet til at måle den organisatoriske læringskapacitet har således ikke haft til hensigt at komme med direkte og konkrete anbefalinger til "how to fix it - easily". Et formål har derimod været at igangsætte refleksioner over, hvordan man helt konkret forstår og arbejder med læring i et organisatorisk perspektiv i en given virksomhed. Især set i lyset af, at når 
talen er på læring i et virksomhedsperspektiv, så er mange ansattes - på alle niveauer i organisationen - umiddelbare forståelse, at læring og udvikling noget, som sker gennem formelle læringsaktiviteter som fx kursusdeltagelse. Med denne artikel sætter vi fokus på, hvordan man kan tænke læring, som noget der også er dybt afhængigt af organisationens strukturelle set-up, ledelsesog videndelingsystemer og organisering af arbejdet. Dermed fremstår den organisatoriske læringskapacitet som andet end alene at være et spørgsmål om at læring automatisk få den ønskede virkning på et organisatorisk niveau ene og alene fra individets deltagelse i en læringsaktivitet.

I forhold til fremtidige forskningsperspektiver er der et behov for at videreudvikle og forbedre på både de teoretiske indsigter såvel som selve måleredskabet bag den empiriske undersøgelse. Der mangler kritiske perspektiveringer af det teoretiske grundlag bag begrebet læringskapacitet, som allerede antydet i denne diskussion. Endvidere mangler vi dybdegående viden om oplevelsen af muligheder og støtte for læring i organisationer baseret på kvalitative data, som vil hjælpe med at nuancere teoriudviklingen af begrebet læringskapacitet, såvel som det også vil gøre os klogere på, hvad helt konkret kendetegner et højt versus et lavt målt læringssystem. Det ville også styrke den forskningsmæssige kvalitet med yderligere variable i selve modellen for organisatorisk læringskapacitet. Dette kunne fx være performance mål, innovation, arbejdsmiljø eller andre typer af virksomhedsdata, til at udvikle forståelsen af læringskapacitet gennem test af hypoteser, som kan gå dybere analytisk end en deskriptiv baseret undersøgelse.

\section{F. Konklusion}

Denne artikel har til formål at introducere begrebet 'organisatorisk læringskapacitet', som det kommer til udtryk og konceptualiseres inden for studiet af organisationer og ledelse med særligt henblik på forskningsområdet organisatorisk læring. Artiklen bruger analyseresultater fra en empirisk undersøgelse i danske virksomheder til at skabe viden om og nuancere forskningen og virksomhedernes forståelse af organisatorisk læringskapacitet. Det overordnede resultatet fra den deskriptive analyse viser, at danske virksomheder generelt har et potentiale for en forbedring af læringskapaciteten, samt at der er signifikante forskelle mellem de organisatoriske læringsmuligheder i offentlige og private virksomheder, mellem leder og medarbejder, samt at der er en stærk sammenhæng mellem læringskapacitet og arbejdsmiljø. Potentialer og begrænsninger i vores viden om begrebet "organisatorisk læringskapacitet" og resultaterne bliver nuanceret og vendt i diskussionen, som både uddyber vores viden - og mangel på viden - om begrebet, og hvordan virksomheder konkret kan arbejde med organisatorisk læringskapacitet i deres ledelsespraksis og organisering af læring i organisationer. 


\section{Referencer}

Alegre, J., and R. Chiva. 2008. "Assessing the impact of organizational learning capability on product innovation performance: An empirical test." Technovation 28 (6):315-326. https://doi.org/10.1016/j.technovation.2007.09.003

Alegre, J., \& Chiva, R. (2013). "Linking entrepreneurial orientation and firm performance: The role of organizational learning capability and innovation performance." Journal of Small Business Management 51(4): 491-507. https://doi.org/10.1111/jsbm.12005

Argote, L. 2011. "Organizational learning research: Past, presence and future." Management learning 42 (4):439-446. https://doi.org/10.1177/1350507611408217

Argote, L., and E. Miron-Spektor. 2011. "Organizational learning: From experience to knowledge." Organization Science 22 (5):1123-1137. https://doi.org/10.1287/orsc.1100.0621

Argyris, C., and D. Schön. 1978. Organizational learning: A theory of action perspective. London: Addison Wesley.

Argyris, C., and D. Schön. 1996. Organizational learning II: Theory, method, and practice. Edited by E. H. Schein, Organizational development. Reading, Massachusetts: Addison Wesley.

Argyris, C., and D. A. Schön. 1974. Theory in practice: Increasing professional effectiveness. San Francisco: Jossey-Bass Publishers. https://doi.org/10.1177/074171367602700109

Bapuji, H., and M. Crossan. 2004. "From questions to answers: Reviewing organizational learning research." Management Learning 35 (4):397-417. https://doi.org/10.1177/1350507604048270

Bontis, N., M. Crossan, and J. Hulland. 2002. "Managing an organizational learning system by aligning stocks and flows." Journal of Management Studies 39 (4):437-469. https://doi.org/10.1111/1467$\underline{6486 . t 01-1-00299}$

Brandi, U., and B. Elkjaer. 2014. "Organisatorisk læring." In Klassisk og moderne organisationsteori, edited by S. Vikkelsoe and P. Kjaer. København: Hans Reitzels Forlag.

Brandi, U., \& Elkjaer, B. (2019). Subtleties of knowledge sharing-Results from a case study within management consultancy. Knowledge and Process Management 26(3): 185-193. https://doi.org/10.1002/kpm.1597

Brandi, U., \& Iannone, R. L. (2017). Learning strategies for competence development in enterprises. Industrial and Commercial Training 49 (1): 1-8. https://doi.org/10.1108/ict-08-2016$\underline{0052}$

Brown, J. S., and P. Duguid. 1991. "Organizational Learning and Communities-of-Practice: Toward a Unified View of Working, Learning, and Innovation." Organization Science 2 (1): 40-57. https://doi.org/10.1287/orsc.2.1.40 
Brown, J. S., and P. Duguid. 2001. "Knowledge and organization: A social-practice perspective." Organization Science 12 (2):198-213. https://doi.org/10.1287/orsc.12.2.198.10116

Camps, J., and R. Luna-Arocas. 2012. "A matter of learning: How human resources affect organizational performance." British Journal of Management 23 (1):1-21. https://doi.org/10.1111/j.1467-8551.2010.00714.x

Cetina, K. K., Theodore R. S., and Eike Von S. 2005. The practice turn in contemporary theory: Routledge.

Chen, Y., G. Tang, F. Lee Cooke, and J. Jin. 2016. "How does executive strategic human resource management link to organizational ambidexterity? An empirical examination of manufacturing firms in china." Human Resource Management 55 (5):919-943. https://doi.org/10.1002/hrm.21797

Chiva-Gómez, Ricardo. 2004. "The facilitating factors for organizational learning in the ceramic sector." Human Resource Development International 7 (2):233-249. https://doi.org/10.1080/1367886042000243817

Chiva, R., and J. Alegre. 2009. "Organizational learning capability and job satisfaction: An empirical assessment in the ceramic tile industry." British Journal of Management 20 (3):323-340. https://doi.org/10.1111/j.1467-8551.2008.00586.x

Chiva, R. 2007. "Measuring organisational learning capability among the workforce." International journal of manpower 28 (3/4):224-242. https://doi.org/10.1108/01437720710755227

Cohen, M. W., and D. A. Levinthal. 1990. "Absorptive capacity: A new perspective on learning and innovation." Administrative Science Quarterly 35 (1):128-152. https://doi.org/10.2307/2393553

Coopey, John, and John Burgoyne. 2000. "Politics and Organizational Learning." Journal of Management Studies 37 (6): 869-885.

Corradi, G., S. Gherardi, and L. Verzelloni. 2010. "Through the practice lens: Where is the bandwagon of practice-based studies heading?" Management Learning 41 (3):265-283. https://doi.org/10.1177/1350507609356938

Czarniawska-Joerges B. and Sevón G. (2003). The northern lights: Organization theory in Scandinavia: Liber.

DiBella, A. J., Nevis, E. C., \& Gould, J. M. (1996). Understanding organizational learning capability. Journal of Management Studies 33(3): 361-379. https://doi.org/10.1111/j.1467$\underline{6486.1996 . t b 00806 . x}$

Dodgson, M., D. M. Gann, and N. Phillips. 2013. "Organizational learning and the technology of foolishness: The case of virtual worlds at ibm." Organization Science 24 (5):1358-1376. https://doi.org/10.1287/orsc.1120.0807 
Easterby-Smith, M., Mary M. Crossan, and D. Nicolini. 2000. "Organizational learning: Debates past, present and future." Journal of Management Studies 37 (6):783-796. https://doi.org/10.1111/14676486.00203

Easterby-Smith, M., and M. A. Lyles. 2011. The evolving field of organizational learning and knowledge management. Edited by M. Easterby-Smith and M. A. Lyles, Handbook of organizational learning and knowledge management. West Sussex: John Wiley \& Sons. https://doi.org/10.1002/9781119207245.ch1

Elkjaer, B. 2004. "Organizational learning: The "third way"." Management Learning 35 (4):419-434. https://doi.org/10.1177/1350507604048271

Escrig, E. D., Broch, F. F. M., Gómez, R. C., \& Alcamí, R. L. (2016). "How does altruistic leader behavior foster radical innovation? The mediating effect of organizational learning capability." Leadership \& Organization Development Journal 37(8): 1056-1082. https://doi.org/10.1108/lodj-03-2015-0050

Feldman, M., and W. Orlikowski. 2011. "Theorizing practice and practicing theory." Organization Science 22 (5):1240-1253. https://doi.org/10.1287/orsc.1100.0612

Felstead, A., A. Fuller, N. Jewson, and L. Unwin. 2009. Improving working as learning: Routledge.

Ferdinand, J. 2004. "Power, politics and state intervention in organizational learning." Management Learning 35 (4): 435-450. https://doi.org/10.1177/1350507604048272

Fuller, Alison, and Lorna Unwin. 2004. "Expansive learning environments: integrating organizational and personal development." In Workplace learning in context, 142-60. London: Routledge.

Gherardi, S. 2000. "Practice-based theorizing on learning and knowing in organizations." Organization 7 (2):211-223. https://doi.org/10.1177/135050840072001

Gherardi, S. 2006. "From organizational learning to practice-based knowing." Human Relations 54 (1):131-139. https://doi.org/10.1177/0018726701541016

Goh, S. C. 2003. "Improving organizational learning capability: Lessons from two case studies." International Journal of Knowledge and Organizational Learning 10 (4):216-228. https://doi.org/10.1108/09696470310476981

Goh, S. C., J. B. Cousins, and C. Elliott. 2006. "Organizational learning capacity, evaluative inquiry and readiness for change in schools: Views and perceptions of educators." Journal of Educational Change 7 (4):289-319. https://doi.org/10.1007/s10833-005-5033-y

Goh, S., and G. Richards. 1997. "Benchmarking the learning capability of organizations." European Management Journal 15 (5):575-583. https://doi.org/10.1016/s0263-2373(97)00036-4 
Graham, C. M., and F. M. Nafukho. 2007. "Employees' perception toward the dimension of culture in enhancing organizational learning." Learning Organization 14 (3):281-292. https://doi.org/10.1108/09696470710739435

Hailekiros, G. S., \& Renyong, H. (2016). "The effect of organizational learning capability on firm performance: Mediated by technological innovation capability." European Journal of Business Management 8(30): 87-95.

He, Zi-Lin, and Poh-Kam Wong. 2004. "Exploration vs. Exploitation: An empirical test of the ambidexterity hypothesis." Organization Science $15 \quad$ (4):481-494. https://doi.org/10.1287/orsc.1040.0078

Hong, J. F. L., M. Easterby-Smith, and R. S. Snell. 2006. "Transferring organizational learning systems to japanese subsidiaries in china." Journal of Management Studies 43 (5):1027-1058. https://doi.org/10.1111/j.1467-6486.2006.00628.x

Jerez-Gómez, P., Céspedes-Lorente, J., \& Pérez-Valls, M. (2017). Do high-performance human resource practices work? The mediating role of organizational learning capability. Journal of Management \& Organization 25(2): 1-22. https://doi.org/10.1017/jmo.2017.55

Levitt, B., and J. G. March. 1988. "Organizational learning." Annual Review of Psychology 14:319340.

Lipshitz, R., M. Popper, and V. J. Friedman. 2002. "A multifacet model of organizational learning." The Journal of applied behavioral science 38 (1):78-98. https://doi.org/10.1177/0021886302381005

Mallén, F., R. Chiva, J. Alegre, and J. Guinot. 2015. "Are altruistic leaders worthy? The role of organizational learning capability." International Journal of Manpower 36 (3): 271-295. https://doi.org/10.1108/ijm-09-2013-0212

March, J. G. 1991. "Exploration and exploitation in organizational learning." Organization Science 2 (1):71-87.

Marsick, V. J., and K. E. Watkins. 2003. "Demonstrating the value of an organization's learning culture: The dimensions of the learning organization questionnaire." Advances in Developing Human Resources 5 (2):132-151. https://doi.org/10.1177/1523422303005002002

Nicolini, D. 2011. "Practice as the site of knowing: insights from the field of telemedicine." Organization Science 22 (3) :602-620. https://doi.org/10.1287/orsc.1100.0556

Orlikowski, W. 2007. "Sociomaterial Practices: Exploring Technology at Work." Organization Studies 28 (3):1435-1449. https://doi.org/10.1177/0170840607081138

Pedler, M., T. Boydell, and J. Burgoyne. 1989. "Towards the learning company." Management learning 20 (1):1-8. 
Popova-Nowak, I. V., and M. Cseh. 2015. "The meaning of organizational learning:A meta-paradigm perspective." Human Resource Development Review 14 (3):299-331. https://doi.org/10.1177/1534484315596856

Preskill, H., and R. T. Torres. 1999. Evaluative inquiry for learning in organizations. Thousand Oaks, CA: Sage.

Schön, Donald A. 1971. Beyond the stable state: Public and private learning in a changing society: Maurice Temple Smith Limited.

Senge, P. 1990. The fifth discipline: The art and practice of the learning organization. New York: Bantam Doubleday.

Seo, M. G., L. L. Putnam, and J. Bartunek. 2004. "Dualities and tensions of planned organizational change." In Handbook of organizational change and innovation, edited by M. D. Poole and A. H. Van de Ven. Oxford: Oxford University Press.

Simon, H. A. 1991. "Bounded Rationality and Organizational Learning." Organization Science 2 (1): 125-34.

Thompson, M. 2005. "Structural and epistemic parameters in communities of practice." Organization Science 16 (2):151-164. https://doi.org/10.1287/orsc.1050.0120

Van Mol, C. 2017. "Improving web survey efficiency: The impact of an extra reminder and reminder content on web survey response." International Journal of Social Research Methodology 20 (4):317327. https://doi.org/10.1080/13645579.2016.1185255

Wenger, E., and W. M. Snyder. 2000. "Communities of practice: The organizational frontier." Harvard Business Review January-February:139-145.

Yang, B., K. E. Watkins, and V. J. Marsick. 2004. "The construct of the learning organization: Dimensions, measurement, and validation." Human Resource Development Quarterly 15 (1):31. https://doi.org/10.1002/hrdq.1086

Yanow, D. 2004. "Translating local knowledge at organizational peripheries*." British journal of management 15 (S1):S9-S25. https://doi.org/10.1111/j.1467-8551.2004.t01-1-00403.X

Xie, L. (2019). "Leadership and organizational learning culture: a systematic literature review." European Journal of Training and Development 43 (1/2): 76-194. 